\title{
DISTRIBUTION OF SOLUBLE AMINO ACIDS IN MAIZE ENDOSPERM MUTANTS
} \author{
Antunes Azevedo** \\ ${ }^{1}$ Depto. de Genética - USP/ESALQ, C.P. 83 - CEP: 13400-970 - Piracicaba, SP. \\ ${ }^{2}$ Depto. Ciências Fisiológicas - UFRRJ/IB - CEP: 23890-000 - Seropédica, RJ. \\ ${ }^{3}$ Depto. de Fisiologia Vegetal - UNICAMP/IB, C.P. 6109 - 13083-970 - Campinas, SP. \\ ${ }^{4}$ Dept. Biological Sciences - Lancaster University, LA1 4YQ - Lancaster, U.K. \\ ${ }^{5} \mathrm{CNPq}$ Fellow. \\ *Corresponding author <raazeved@esalq.usp.br>
}

Alejandro Alberto Toro ${ }^{1,5}$; Leonardo Oliveira Medici2; Ladaslav Sodek ${ }^{3}$; Peter John Lea ${ }^{4}$; Ricardo

\begin{abstract}
For human nutrition the main source of vegetable proteins are cereal and legume seeds. The content of total soluble amino acids in mature endosperm of wild-type, opaque and floury maize (Zea mays L.) mutants were determined by HPLC. The total absolute concentration of soluble amino acids among the mutants varied depending on the mutant. The 011 and 013 mutants exhibited the highest average content, whereas $010, \mathrm{fl} 3$ and $\mathrm{fl} 1$ exhibited the lowest average content. In general, the mutants exhibited similar concentrations of total soluble amino acids when compared to the wild-type lines, with the clear exception of mutants 011 and $\mathrm{fl} 1$, with the 011 mutant exhibiting a higher concentration of total soluble amino acids when compared to its wild-type counterpart W22 and the fl1 mutant a lower concentration when compared to its wild-type counterpart Oh43. For methionine, the mutants 02 and 011 and wild-type Oh43 exhibited the highest concentrations of this amino acid. Significant differences were not observed between mutants for other amino acids such as lysine and threonine. The high lysine concentrations obtained originally for these mutants may be due to the amino acids incorporated into storage proteins, but not those present in the soluble form.

Key words: Zea mays, lysine, threonine, methionine
\end{abstract}

\section{DISTRIBUIÇÃO DE AMINOÁCIDOS SOLÚVEIS EM ENDOSPERMAS MUTANTES DE MILHO}

\begin{abstract}
RESUMO: A principal fonte de proteínas vegetais para alimentação humana e animal é fornecida pelos grãos de cereais e leguminosas. O conteúdo de aminoácidos solúveis totais foi determinado por HPLC em endospermas de milho (Zea mays L.) normal e mutantes opaco e floury. A concentração de aminoácidos solúveis totais variou entre os mutantes. Os mutantes 011 e 013 se destacaram com médias superiores, enquanto que mutantes 010, fl3 e fl1 apresentaram as menores médias. De maneira geral, para a concentração total de aminoácidos solúveis, os grãos dos mutantes foram similares aos seus tipos selvagens com exceção dos mutantes 011 e fl1 sendo que o primeiro apresentou valor maior que seu tipo selvagem W22, enquanto que o fl1 teve valor menor que o Oh43. Para metionina, os mutantes 02 e 011 e o tipo selvagem Oh43 apresentaram as mais altas concentrações deste aminoácido. Valores similares foram observados entre os mutantes e os tipos selvagens para concentração de outros aminoácidos analisados, tais como lisina e treonina. As altas concentrações sugeridas originalmente para estes mutantes devem ser devidas aos níveis destes aminoácidos incorporados nas proteínas de reserva, mas não na forma solúvel.
\end{abstract}

Palavras-chave: Zea mays, lisina, metionina, treonina

\section{INTRODUCTION}

The main source of proteins in plants is grains of legumes and cereals. Among cereals, maize and rice represent the staple food for most part of the population of Latin American countries, Africa and Asia. Brazil is one of the most important maize producers of the world, with a production of 33.038.068 Mt (FAO, 2000). However, maize is a relatively poor cereal when it comes to the quality of its protein, because it has limiting amounts of two essential amino acids, lysine and tryptophan (Azevedo et al., 1997).

Among the amino acids normally found in proteins, only 11 can be synthesized by adult animals.
The other amino acids, referred to as essential amino acids, must be acquired through the diet. Plants, most bacteria and fungi have the ability to synthesize all twenty amino acids. Among the essential amino acids, lysine is synthesized through the aspartic acid metabolic pathway, which also leads to the formation of threonine, methionine and isoleucine (Azevedo et al., 1997; Azevedo \& Lea, 2001). Regulation of the aspartic acid pathway occurs by negative or positive feedback from key enzymes (Molina et al., 2001). Some of them, such as aspartate kinase $(\mathrm{AK})$, homoserine dehydrogenase $(\mathrm{HSDH})$ and dihydrodipicolinate synthase (DHDPS), involved in lysine and threonine synthesis, were identified as major points of carbon flow control, through the pathway. The lysine 
synthesis branch that begins with DHDPS is followed by the degradation pathway that comprises the action of the bifunctional enzyme lysine 2-oxoglutarate reductase/ saccharopine dehydrogenase (LOR/SDH) (Azevedo et al., 1997; Gaziola et al., 1997; Gaziola et al., 2000; Azevedo \& Lea, 2001).

Storage proteins present in maize endosperm can be classified, based on their solubility (Osborne \& Mendel, 1914; Landry \& Moureaux, 1970), as albumins, globulins, prolamins (called zeins) and glutelins. Zeins are the most abundant proteins as they represent $60 \%$ or more of the total protein content in the endosperm (Gaziola et al., 1999).

Many endosperm mutations are characterized by a change in the synthesis of storage proteins in maize seeds (Molina et al., 2001). The most studied and utilized mutants in breeding programs aiming at maize protein quality have been the opaque-2 (o2) (Gaziola et al., 1999) and the floury-2 (fl2) (Nelson et al., 1965). The o2 gene has been mapped on chromosome 7 and segregates as a simple recessive gene; the $\mathrm{fl} 2$ gene, however, is codominant and is located in chromosome 4 (Kodrzycki et al., 1989).

The 02 mutant differs from wild-type maize in the amount and distribution of endosperm proteins, with a decrease in the proportion of zeins and a large increase in glutelins, globulins and albumins (Gaziola et al., 1999). The total amount of amino acids in the endosperm of the mutant lines is also higher than in the wild-type genotypes that were their ancestors (Sodek \& Wilson, 1971), with a specific increase especially in lysine and a decrease in glutamic acid, proline and leucine (Sodek \& Wilson, 1971). The fl 2 mutant has higher concentration of glutelins, with little effect on zeins, resulting in a slight increase in lysine concentration as compared to wild-type genotypes (Sodek \& Wilson, 1971). Other studies aimed at characterizing the opaque-7 (o7) mutant indicated high amino acid levels in the mutant (Ma \& Nelson, 1975). In a similar way, high lysine levels have been reported in the floury-3 (fl3) mutant as compared to wild-type maize (Ma \& Nelson, 1975).

Even though the 02 gene is able to change favorably the amount of amino acids in the grains of maize, its use in agriculture has been limited due to the reduced yield and undesirable grain characteristics, such as low consistence and a farinaceous endosperm that retains water, affecting harvest and contributing to an increase of the susceptibility to diseases (Gupta et al., 1970; Loesch et al., 1976). As a consequence of this, research has been directed toward selecting aspartic acid metabolic pathway mutants with enzymes less sensitive to feedback inhibition, by means of mutagenic agents or cell cultures supplemented with toxic levels of amino acids or their analogs (Azevedo et al., 1997; Azevedo \& Lea, 2001; Azevedo, 2002). Such mutants have shown variation relative to some amino acids, but not to lysine. Transgenic plants have been produced based on the same principle of biochemical mutants, but plants with a high lysine content in the grains were again not obtained (Azevedo, 2002).

This information suggests that the amount of lysine in cereal grains could be dependent upon the manipulation of the enzymes LOR and SDH, which are involved in lysine degradation (Molina et al., 2001), as observed for the 02 mutant, which has reduced activity for these enzymes when compared to wild-type genotypes (Brochetto-Braga et al., 1992).

In this work, we have analyzed the levels of total soluble amino acids and the aspartic acid metabolic pathway products: lysine, threonine and methionine, in mature grains of different mutant genotypes of maize 01, 02, 05, 07, 010, 011, 013, fl1, fl2 and fl3, which have never been characterized in detail in regard to any aspect related to amino acid metabolism, and particularly to lysine.

\section{MATERIAL AND METHODS}

Anthers and grains of different lines of maize were utilized. Grains of the mutant genotypes opaque (01, 02, 05, 07, 010, 011 and 013) and floury (fl1, fl2 and $\mathrm{fl}$ ) and their respective wild-types were provided by the Maize Genetics Cooperation Stock Center (Urbana, Illinois, USA). The wild-type genotypes utilized as control for the mutant lines were Oh43 for o1, 02, 013, fl1 and fl2; B37 for 07; W22 for 010, 011 and 013; B79 for 05; and WT3 for fl3. The wild-type maize inbred line N6, from the Escola Superior de Agricultura Luiz de Queiroz, Universidade de São Paulo, maize seed bank, was also utilized as an internal control. Plants were grown in a glasshouse and auto-pollinated, during the summer of 2001, and ears with dry grains were harvested for amino acid quantification. Anthers were collected before anthesis and stored at $-80^{\circ} \mathrm{C}$ for further amino acid analysis.

Soluble amino acids were extracted as described by Azevedo et al. (1990), using $0.05 \mathrm{~g}$ of anthers. Samples were homogenized with a glass rod in $50 \mu \mathrm{L}$ of Milli-Q water. Then, the extracts were centrifuged twice at $15,000 \mathrm{rpm}$ for $15 \mathrm{~min}$ at $4^{\circ} \mathrm{C}$ and the supernatants were utilized for the amino acid analyses.

Silica gel-polyester TLC plates measuring $20 \mathrm{~cm}$ x $20 \mathrm{~cm}$ (Sigma-Aldrich, St. Louis, MO, USA) were utilized for the soluble amino acid qualitative analysis. Ten $\mu \mathrm{L}$ of anther free amino acid extracts were applied onto the chromatography plates. The plates were activated at $80^{\circ} \mathrm{C}$ for 60 min prior to the application of the samples. The chromatograms were developed in a glass chamber containing a solution of butyl alcohol, acetone, ammonium hydroxide, and deionized water (50:50:25:10 $\mathrm{mL})$. After separation of the amino acids, the plates were dried in a ventilated fume cupboard for $48 \mathrm{~h}$ at room temperature. The amino acids spots were revealed with 
a $0.2 \%$ ninhydrin solution in acetone $(w / v)$. Amino acid standards were included for amino acid identification, with a special interest in lysine.

The procedure for amino acid extraction by HPLC in reverse phase was based on the technique published by Bielesky \& Turner (1986), with some modifications. A refined flour was obtained by macerating $0.1 \mathrm{~g}$ of grain; the flour was homogenized in $2.0 \mathrm{~mL}$ of a MCW extraction solution $(12.0 \mathrm{~mL}$ methanol, $5.0 \mathrm{~mL}$ chloroform and $3.0 \mathrm{~mL}$ bidistilled water) and incubated for $12 \mathrm{~h}$ at $4^{\circ} \mathrm{C}$. The extracts were centrifuged at $2,500 \mathrm{rpm}$ for $20 \mathrm{~min}$ at $4^{\circ} \mathrm{C}$ and the supernatant was mixed with $0.5 \mathrm{~mL}$ chloroform and 0.75 $\mathrm{mL}$ bidistilled water. The solution was centrifuged once again and the supernatant was maintained at $38^{\circ} \mathrm{C}$ for $2 \mathrm{~h}$. After this period, the supernatant was frozen and submitted to freeze-drying for $48 \mathrm{~h}$. For each freezedried sample, $250 \mu \mathrm{L}$ of milli-Q water were added. The amino acid solution was then filtered through a $0.22 \mu \mathrm{m}$ membrane (Millipore Ind. e Com. Ltda, São Paulo, SP, Brazil) to be utilized in a final concentration of $125 \mathrm{nmol}$ $\mathrm{mL}^{-1}$. The HPLC analyses used $20 \mu \mathrm{L}$ of the amino acid solution and $40 \mu \mathrm{L}$ of o-phthaldialdehyde solution (OPA).

The soluble amino acids were separated and analyzed by reverse-phase HPLC. A Spherisorb ODS-2 C18 column was utilized with $0.8 \mathrm{~mL} \mathrm{~min}^{-1}$ elution for a linear gradient formed by solutions of $65 \%$ methanol and $\mathrm{pH} 7.5$ phosphate buffer $(50 \mathrm{mM}$ sodium acetate, $50 \mathrm{mM}$ disodium phosphate, $1.5 \mathrm{~mL}$ acetic acid, $20 \mathrm{~mL}$ tetrahydrofuran and $20 \mathrm{~mL}$ methanol in $1 \mathrm{~L}$ water). The gradient increased the proportion of methanol from 20 to $28 \%$ between 0 and $5 \mathrm{~min}$, from 28 to $58 \%$ between 5 and $35 \mathrm{~min}$, from 58 to $75 \%$ between 35 and $40 \mathrm{~min}, 75$ to $95 \%$ between 40 and 56 min, 95 to $96 \%$ between 56 and $60 \mathrm{~min}$, and 96 to $100 \%$ between 60 and $61 \mathrm{~min}$. The amino acids eluting from the column were monitored by a Shimatdzu (model RF350) fluorescence detector operating on a $250 \mathrm{~nm}$ excitation wavelength and a 480 $\mathrm{nm}$ emission wavelength. Twenty $\mu \mathrm{L}$ of the amino acid solution and $40 \mu \mathrm{L}$ of the OPA solution were mixed. After $2 \mathrm{~min}, 20 \mu \mathrm{L}$ of the amino acids derivatized with OPA were injected into the HPLC detector. Data are expressed as nmol mL $\mathrm{m}^{-1}$ of supernatant and as \%mol of the total amino acids recovered (excluding proline that does not form a derivative with OPA). A standard solution containing all amino acids was derivatized with OPA as described above and utilized for column profile and elution sequence identification.

The analysis of variance was performed with the aid of the SAS software (SAS Institute, 1993), and the means of variables presenting significance in the analysis were compared by the Duncan test. The \%mol of methionine $X$ data were transformed in $\sqrt{X+10}$, and the $\mathrm{nmol} \mathrm{mL} \mathrm{L}^{-1}$ total amino acid and methionine data $Y$ were transformed in $L n(Y+10)$. These transformations were chosen based on the distribution pattern of the data. The experimental design was completely randomized with three replicates for the mutant lines. The wild-type controls were quantified with one replicate and for this reason they were excluded from the statistical analyses; however, they were included in the tables of means to allow comparisons between magnitudes of values. The criterion arbitrated for comparison between magnitudes of values involving wild-type lines was based on the least significant difference obtained with mutant lines for the Duncan test, without ascribing a statistical confidence to these magnitude comparisons.

\section{RESULTS AND DISCUSSION}

The 02 mutant has been characterized for agronomic and biochemical aspects, including amino acids and storage proteins. However, very little or no information is available for several other mutants related to the opaque and floury classes of mutations. This is the first report presenting the characterization of maize endosperm mutants for absolute and relative amounts of soluble amino acids in grains.

Differences were observed for total amino acids (prob. $>\mathrm{F}=0.0155$ ) and methionine levels (prob. $>\mathrm{F}=$ 0.0115 ) between mutant grains, but were not observed for lysine (prob. $>F=0.7602$ ) and threonine (prob. $>F=$ 0.8518 ) levels. For lysine and threonine, the magnitudes of the values between mutants and wild-types were similar. With regard to proportions of amino acids in the grain, differences between mutants were detected for methionine (prob. $>\mathrm{F}=0.0142$ ), but not for threonine (prob. $>F=0.7633$ ) and lysine (prob. $>F=0.7600$ ).

In terms of total amino acid amounts (Table 1), grain from lines $011\left(1898.84 \mathrm{nmol} \mathrm{mL}^{-1}\right)$ and 013 $\left(1758.80 \mathrm{nmol} \mathrm{mL}^{-1}\right)$ were prominent with higher means, while grain from lines $010\left(592.57 \mathrm{nmol} \mathrm{mL}{ }^{-1}\right), \mathrm{fl} 3$ $\left(493.67 \mathrm{nmol} \mathrm{mL}^{-1}\right)$ and fl1 $\left(479.30 \mathrm{nmol} \mathrm{mL} \mathrm{L}^{-1}\right)$ contained the lowest means. In general, the mutant grains had values similar to their wild-types with the exception of 011 and fl1. The first had a value higher than the wildtype W22, whilst fl1 was lower than Oh43. No differences were observed between mutant genotypes at $1 \%$.

As to absolute levels of soluble methionine (Table 1), at $5 \%$, grain from lines $02\left(64.53 \mathrm{nmol} \mathrm{mL}^{-1}\right)$ and 011 $\left(36.79 \mathrm{nmol} \mathrm{mL}^{-1}\right)$ were superior with the highest means, while the lowest means were observed for the mutants $07\left(11.27 \mathrm{nmol} \mathrm{mL}^{-1}\right)$ and $01\left(10.63 \mathrm{nmol} \mathrm{mL}^{-1}\right)$. Most mutants had values close to their wild-type counterparts, except 011 and 013 , which exhibited higher values than those of line W22. The observed performance of 02 grains was superior to the $010, f|2, f| 1, f \mid 3,07$ and 01 mutants at $1 \%$.

With regard to relative values of methionine at $5 \%$ (Table 1), mutants o2 $(3.65 \% \mathrm{~mol})$ and $\mathrm{fl} 1(3.37 \% \mathrm{~mol})$, $010(2.99 \% \mathrm{~mol})$ and $\mathrm{fl} 3(2.78 \% \mathrm{~mol})$ can be considered superior, while the smallest means occurred for lines 05 
Table 1 - Total soluble amino acids and soluble methionine means, expressed as absolute values $\left(\mathrm{nmol} \mathrm{mL} \mathrm{m}^{-1}\right)$, and in the case of methionine also as relative values $(\% \mathrm{~mol})$, in grain of wild-type and mutant maize genotypes.

\begin{tabular}{|c|c|c|c|c|}
\hline Genotype & Original mean & Transformed Mean* & $5 \%$ & $1 \%$ \\
\hline \multicolumn{5}{|c|}{ Soluble amino acids } \\
\hline \multicolumn{5}{|c|}{ - } \\
\hline Oh43 & 2501.35 & 7.829 & & \\
\hline Opaco-11 & 1898.84 & 7.554 & a & A \\
\hline Opaco-13 & 1758.80 & 7.478 & a & A \\
\hline Opaco-2 & 1674.76 & 7.429 & $a b$ & A \\
\hline Opaco-5 & 1174.30 & 7.077 & $a b c$ & A \\
\hline Floury-2 & 748.06 & 6.631 & $a b c$ & A \\
\hline Opaco-1 & 725.03 & 6.600 & $a b c$ & A \\
\hline Opaco-7 & 646.55 & 6.487 & C & A \\
\hline Opaco-10 & 592.57 & 6.401 & C & A \\
\hline B79 & 501.07 & 6.237 & & \\
\hline Floury-3 & 493.67 & 6.222 & c & A \\
\hline Floury-1 & 479.30 & 6.191 & C & A \\
\hline B37 & 442.40 & 6.115 & & \\
\hline W22 & 292.28 & 5.711 & & \\
\hline WT3 & 207.21 & 5.381 & & \\
\hline \multicolumn{5}{|c|}{ Soluble methionine } \\
\hline \multicolumn{5}{|c|}{---------------------- nmol mL-1 --------------------- } \\
\hline Opaco-2 & 64.53 & 4.311 & a & A \\
\hline Oh43 & 64.48 & 4.311 & & \\
\hline Opaco-11 & 36.79 & 3.846 & $a b$ & $A B$ \\
\hline Opaco-13 & 29.40 & 3.674 & $b c$ & $A B$ \\
\hline Opaco-5 & 27.97 & 3.637 & $b c$ & $A B$ \\
\hline Opaco-10 & 17.66 & 3.320 & $b c$ & B \\
\hline Floury-2 & 16.06 & 3.260 & $b c$ & B \\
\hline Floury-1 & 15.89 & 3.254 & bc & B \\
\hline Floury-3 & 14.91 & 3.215 & $b c$ & B \\
\hline B79 & 12.68 & 3.121 & & \\
\hline WT3 & 11.36 & 3.061 & & \\
\hline Opaco-7 & 11.27 & 3.057 & C & B \\
\hline Opaco-1 & 10.63 & 3.027 & C & B \\
\hline W22 & 10.17 & 3.004 & & \\
\hline B37 & 5.29 & 2.727 & & \\
\hline
\end{tabular}

\begin{tabular}{|c|c|c|c|c|}
\hline \multicolumn{5}{|c|}{ Soluble methionine } \\
\hline -------- & $\ldots$ & $\mid$ & $-\cdots--$ & --- \\
\hline WT3 & 5.48 & 3.934 & & \\
\hline Opaco-2 & 3.65 & 3.685 & a & A \\
\hline W22 & 3.48 & 3.672 & & \\
\hline Floury-1 & 3.37 & 3.657 & $a b$ & $A B$ \\
\hline Opaco-10 & 2.99 & 3.605 & $a b c$ & $A B$ \\
\hline Floury-3 & 2.78 & 3.575 & abcd & $A B$ \\
\hline Oh43 & 2.58 & 3.547 & & \\
\hline B79 & 2.53 & 3.540 & & \\
\hline Floury-2 & 2.07 & 3.474 & bcd & $A B$ \\
\hline Opaco-11 & 2.00 & 3.463 & bcd & $A B$ \\
\hline Opaco-5 & 1.82 & 3.438 & $c d$ & $A B$ \\
\hline Opaco-13 & 1.82 & 3.438 & $c d$ & $A B$ \\
\hline Opaco-7 & 1.74 & 3.426 & $c d$ & B \\
\hline Opaco-1 & 1.56 & 3.400 & $d$ & B \\
\hline B37 & 1.19 & 3.345 & & \\
\hline
\end{tabular}

Means followed by different letters indicate differences at the used probability levels.

*Used transformations: soluble amino acids and methionine (nmol $\left.\mathrm{mL}^{-1}\right): y=(\ln x+10)$; soluble methionine $(\% \mathrm{~mol}): y=(x+10)^{1 / 2}$
(1.82\% mol), o13 $(1.82 \% \mathrm{~mol}), 07(1.74 \% \mathrm{~mol})$ and 01 $(1.56 \% \mathrm{~mol})$. Most mutants produced levels similar to those shown by their wild-types, except for 011 , 01 and 013 , which exhibited lower values than those of their wildtypes W22 and Oh43. At 1\%, o2 exhibited higher relative amounts of methionine only when compared to mutants 07 and 01.

Maize anther extracts were also utilized to carry out qualitative analyses of free lysine by TLC (Figure 1), in an attempt to preliminarily identify highly significant variations in the concentration of lysine in the different mutant genotypes in relation to the wild-types. The results obtained did not allow a clear discrimination between different genotypes, at least in regard to levels of free lysine, since this technique is basically used to observe very contrasting patterns as, for example, those observed for the maize mutant ask1, which accumulated 144 times more threonine in the anther as compared to wild-type maize, allowing a previous identification in the field of plants with genotype ask1, in order to utilize exclusively ask 1 plants in further crossings (Azevedo et al., 1990).

The analyses performed by TLC and HPLC were carried out to characterize differences among mutant genotypes as well as among the original wild-type genotypes. Differences were observed in total amino acid levels and in methionine between mutants. However, for the amino acids lysine and threonine, no differences were observed.

An analysis of the proportion of methionine relative to the total amino acids in the grain, suggests a different distribution of soluble amino acids among the lines under study, considering that the soluble amino acids represent between $6-8 \%$ of the total amino acids in the wild-type grain. It would be interesting to analyze the soluble amino acids fraction, as well as the amino acids incorporated into storage proteins in the grain, both

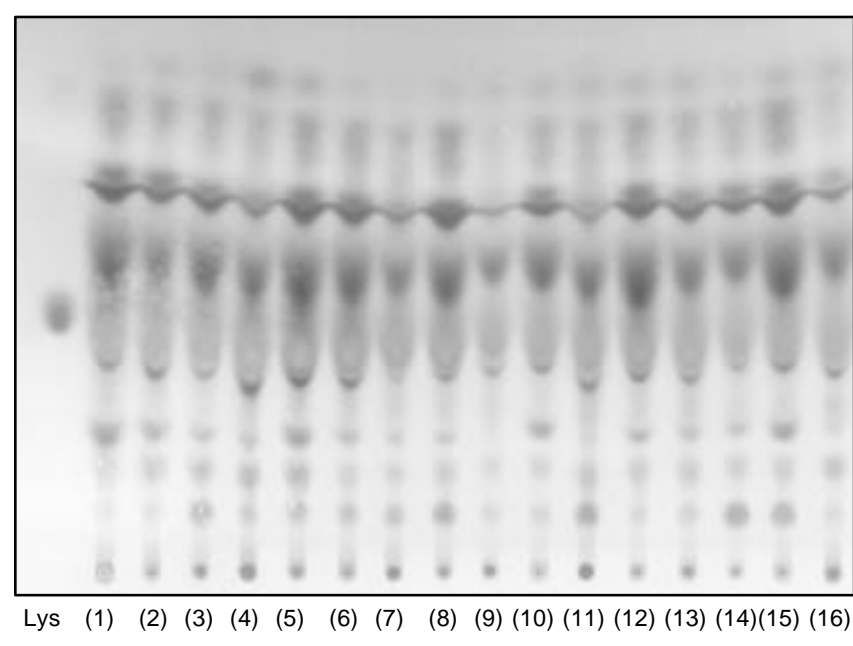

Figure 1 - Soluble lysine analysis of anthers of wild-type and mutant maize genotypes by thin layer chromatography (TLC). Lines represent (1) N6-ESALQ; (2) W22; (3) Oh43; (4) WT3; (5) B79; (6) B37; (7) o1; (8) 02; (9) 05; (10) o7; (11) 010; (12) 011; (13) o13; (14) fl1; (15) fl2; (16) fl3. 
qualitative and quantitatively, and then compare them to the amino acid profile of a standard protein of animal origin with high biological value, for example, cow milk or chicken egg proteins. This would allow supplementary and relevant information to be obtained in relation to the amino acid profile as well as to the biological value of proteins in the lines under study.

Higher values of soluble lysine in the mutants were not observed when compared to their wild-type counterparts, which is different from other previously published reports, in which consistent differences have been observed, with higher amounts of lysine in the mutants (Sodek \& Wilson, 1971; Gaziola et al., 1999; Wang \& Larkins, 2001). Most research has been carried out in order to provide information on the total soluble amino acid content of maize endosperm, where the levels of soluble amino acids and amino acids incorporated into proteins are considered collectively (Ma \& Nelson, 1975; Balconi et al., 1998). In a recent paper, Wang \& Larkins (2001) reported high soluble lysine concentrations in the mature endosperm of line W64Ao2, as compared to wildtype lines.

In the case of the floury mutants, the endosperm of $\mathrm{fl} 2$ had a lower proportion of soluble amino acids (Sodek \& Wilson, 1971) and a higher amount of total amino acids (Sodek \& Wilson, 1971). No information concerning the concentrations of soluble amino acids is available for the endosperm of $\mathrm{fl} 3$, but from acid hydrolysis of storage proteins (Ma \& Nelson, 1975) and colorimetric techniques for lysine quantification (Balconi et al., 1998), increases in the proportion of lysine relative to the amounts present in wild-type endosperm have been observed. Balconi et al. (1998) also determined higher levels of lysine in A69yo1 and A69yo11 endosperms.

More pronounced differences in the amounts of soluble amino acids between mutants and wild-type inbred lines have been observed during the development of the endosperm, as a consequence of amino acid transportation from the phloem to endosperm cells, as well as synthesis in situ (Silva \& Arruda, 1979). In the developing 02 endosperm, the high lysine levels (Silva \& Arruda, 1979; Gaziola et al., 1999) coincide with the decreased synthesis of zein proteins (Sodek \& Wilson, 1971; Yau et al., 1999) and with the lower activity of the bifunctional enzyme LOR/SDH (Brochetto-Braga et al., 1992; Gaziola et al., 1999). However, the activity of this bifunctional protein during the maturation process of the grain would degrade the lysine not incorporated into proteins, decreasing the soluble concentration even further (Galili, 1995).

No differences in the amount of soluble threonine have been recorded in this study, which agrees with results previously obtained in $\mathrm{R} 80202$ (Sodek \& Wilson, 1971) and W64Ao2 (Wang \& Larkins, 2001) maize endosperms; nonetheless, these data differ from the results obtained for the endosperm of Oh54502, which exhibited significant increases in soluble threonine (Wang
\& Larkins, 2001). This suggests two key aspects that reveal the importance of the interaction between the 02 gene and the genetic background where it will be expressed and where its phenotypic effects will be evaluated.

A broader characterization of soluble and total amino acid concentrations incorporated into proteins must be performed, together with other biochemical and molecular analyses, to allow a better understanding of the patterns of regulation and control of metabolic pathways that govern the metabolism of essential amino acids, especially lysine, tryptophan, threonine and methionine.

\section{CONCLUSIONS}

The observations that no variations in soluble lysine content were detected in the maize endosperm mutants analyzed is contrary to what initially had been suggested when these mutants were isolated. These results can probably be explained by a change in the storage distribution pattern of proteins in these mutants, such as the observed for mutant 02 , suggesting that the presumed increase in lysine is due to the amounts incorporated into storage proteins, but not that in the soluble form.

\section{ACKNOWLEDGEMENTS}

To FAPESP (98/12461-0 and 01/13904-8) and the British Council for financial support and to CNPq for scholarships granted to the first and last authors.

\section{REFERENCES}

AZEVEDO, R.A. Analysis of the aspartic acid metabolic pathway using mutant genes. Amino Acids, v.22, p.217-230, 2002.

AZEVEDO, R.A.; ARANA, J.L.; ARRUDA, P. Biochemical genetics of the interaction of the lysine plus threonine resistant mutant $I t r^{\star} 1$ with opaque2 maize mutant. Plant Science, v.70, p.81-90, 1990.

AZEVEDO, R.A.; ARRUDA, P.; TURNER, W.L.; LEA, P.J. The biosynthesis and metabolism of the aspartate derived amino acids in higher plants. Phytochemistry, v.46, p.395-419, 1997

AZEVEDO, R.A.; LEA, P.J. Lysine metabolism in higher plants. Amino Acids, v.20, p.261-279, 2001.

BALCONI, C.; BERARDO, N.; REALI, A.; MOTTO, M. Variation in protein fraction and nitrogen metabolism of developing normal and opaque endosperm mutants of maize. Maydica, v.43, p.195-203, 1998.

BIELINSKY, R.L.; TURNER, N.A. Separation and estimation of amino acids in crude plant extracts by thin-layer electrophoresis and chromatography. Analytical Biochemistry, v.17, p.278-293, 1986.

BROCHETTO-BRAGA, M.R.; LEITE, A.; ARRUDA, P. Partial purification and characterization of lysine-ketoglutarate reductase in normal and opaque2 maize endosperms. Plant Physiology, v.98, p.1139-1147, 1992.

FAO. FAOSTAT Agriculture Data. http://www.Fao.org/page/ collections?subset=agriculture (20 Nov. 2001).

GALILI, G. Regulation of lysine and threonine synthesis. Plant Cell, v.7, p.899906, 1995.

GAZIOLA, S.A.; ALESSI, E.S.; GUIMARÃES, P.E.O.; DAMERVAL, C.; AZEVEDO, R.A. Quality protein maize: a biochemical study of enzymes involved in metabolism. Journal of Agricultural and Food Chemistry, v.47, p.1268-1275, 1999.

GAZIOLA, S.A.; SODEK, L.; ARRUDA, P.; LEA, P.J.; AZEVEDO, R.A. Degradation of lysine in rice seeds: Effect of calcium, ionic strength, $S$ adenosylmethionine and $S$-2-aminoethyl-L-cysteine on the lysine 2 oxoglutarate reductase-saccharopine dehydrogenase bifunctional enzyme. Physiologia Plantarum, v.110, p.164-171, 2000. 
GAZIOLA, S.A.; TEIXEIRA, C.M.G.; LUGLI, J.; SODEK, L.; AZEVEDO, R.A The enzymology of lysine catabolism in rice seeds: Isolation, characterization and regulatory properties of lysine 2-oxoglutarate reductase/saccharopine dehydrogenase bifunctional polypeptide. European Journal of Biochemistry, v.247, p.364-371, 1997.

GUPTA, S.C.; ASNANI, V.L.; KHARE, B.P. Effect of the opaque-2 gene in maize (Zea mays L.) on the extent of infestation by Sitophilus oryzae L. Journal of Stored Products Research, v.6, p.191-194, 1970.

KODRZYCKI, R.; BOSTON, R.S.; LARKINS, B.A. The opaque-2 mutation of maize differentially reduces zein gene transcription. Plant Cell, v.1, p.105 114,1989

LANDRY, J.; MOUREAUX, T. Hétérogénéité des glutélines du grain de mais: extration sélective et composition en acids aminés des trois fractions isolées. Bulletin de la Societe de Chimie Biologique, v.52, p.1021-1037, 1970.

LOESCH, P.J.; FOLEY, D.C.; COX, D.F. Comparative resistance of opaque-2 and normal inbred lines of maize to ear-rotting pathogens. Crop Science, v.16, p.841-842, 1976

MA, Y.; NELSON, O.E. Amino acid composition and storage proteins in two new high-lysine mutants in maize. Cereal Chemistry, v.52, p.412-419, 1975.

MOLINA, S.M.G.; GAZIOLA, S.A.; LEA, P.J.; AZEVEDO, R.A. Manipulação de cereais para acúmulo de lisina em cereais. Scientia Agricola, v.58, p.205-211, 2001
NELSON, S.O.; MERTZ, E.T.; BATES, L.S. Second mutant gene affecting the amino acid pattern of maize endosperm protein. Science, v.150, p.1469-1470, 1965

SAS Institute Inc. SAS/STAT User's guide: Version 6.124 ed. Carey, NC: SAS Institute, v.2, cap.24, p.891-996, 1993

OSBORNE, T.B.; MENDEL, L.B. Nutritive properties of proteins of the maize kernel. Journal of Biological Chemistry, v.18, p.1-6, 1914

SILVA, W.J.; ARRUDA, P. Evidence for the genetic-control of lysine catabolism in maize endosperm. Phytochemistry, v.18, p.1803-1805, 1979

SODEK, L.; WILSON, C.M. Amino acid composition of proteins isolated from normal, opaque-2, and floury-2 maize endosperm by a modified Osborne procedure. Journal of Agricultural and Food Chemistry, v.19, p.11441150, 1971.

WANG, X.; LARKINS, B.A. Genetic analysis of amino acid accumulation in opaque-2 maize endosperm. Plant Physiology, v.125, p.1766-1777, 2001.

YAU, J.C.; BOCKHOLT, A.J.; SMITH, J.D.; ROONEY, L.W.; WANISKA, R.D. Maize endosperm proteins that contribute to endosperm lysine content. Cereal Chemistry, v.76, p.668-672, 1999.

Received January 9, 2002 